\title{
Challenges and perspectives in sustainable management of natural resources at regional level
}

\author{
Margarita R.Tsibulnikova \\ Department of Economics of Natural Resources \\ National Research Tomsk Polytechnic University \\ Tomsk, Russia \\ E-mail: tsibulnikova2011@yandex.ru
}

\author{
Olga V. Pogharnitskaya \\ Department of Economics of Natural Resources \\ National Research Tomsk Polytechnic University \\ Tomsk, Russia \\ E-mail: pov@tpu.ru
}

\author{
Aleksandr M. Adam \\ Department of Environmental Management \\ National Research Tomsk State University \\ Tomsk, Russia \\ E-mail: adam.green@tsu.ru
}

\begin{abstract}
The paper considers natural capital accounting and valuation as crucial factors for management decision-making, which is aimed at economic diversification and sustainable development and ensures efficient exploration, consumption, and replenishment of natural resources. Tomsk Oblast serves as an example for implementing natural capital and ecosystem service valuation into management decision making.

The authors have determined the possibility and estimated readiness of local authorities to account economic benefits and losses in ecosystem management. The materials used in the study are data of Russian state statistics, strategic plans and regulations of Tomsk Oblast, the departmental information, and the outcomes of previous research on the natural capital valuation in Tomsk Oblast. The authors give reasons for institutional changes necessary to account and valuate all functions of the natural capital and ecosystem when making management decisions. This means that there should be a system of economic value monitoring for natural resource management, which implies economic-ecological accounting and is represented as a complex of integrated statistical factors giving natural capital information. The authors also suggest the mechanism to design information and methodological basis for natural capital economic valuation. The new information basis integrated into the regional government system will provide data on costs and benefits in natural resource management and ensure interaction between the authorities, municipal organizations, companies, and public.
\end{abstract}

Keywords - sustainable development, natural capital, ecosystem services, economic valuation, natural resource management

\section{INTRODUCTION}

Local authorities in different countries face challenges on their way to sustainable development: they have to choose between resource-based economy, with natural resources being a source of "quick income", and ecosystem conservation for the further use of ecosystem services. Transition to sustainable development implies valuing the natural capital and a wide range of ecosystem services [1]. This causes a shift from the out-of-date trend in using natural resources, i.e. resources extraction, to valuing the environment on different aspects of human-environment interaction [2]. Natural resource management activities are carried out under the constantly changing conditions [3], which requires a flexible management system including environmental impact monitoripng [4, 5].

Regarding the concept of sustainable development in terms of economics, the area aggregate capital stock includes human, physical, and natural capitals. The recent studies are shedding new light on the complicated interaction of these capitals. The natural capital contribution to the human well-being is ecosystem services, which are not supplied directly, but through the interaction of the natural capital with the other area capitals [6]. As it was mentioned in the WAVES Global Partnership annual report (Wealth Accounting and the Valuation of Ecosystem Services) [7], more and more middle income countries are implementing natural capital accounting into management decision making.

The economic assessment of ecosystem services has lately become the focus of international attention. The currently implemented international projects are the Natural Capital Projectl and the Economics of Ecosystems and Biodiversity (TEEB) [8]. The aim of the Natural Capital Project is to integrate the value nature provides to society into all major decisions, which have impact on the environment and wellbeing of people. The TEEB is focused on creating economicecological basis for the development and making nature's values visible. The efficient natural capital management implies distribution of costs and benefits over the whole range of ecosystem services and preferential treatment of the least protected social classes.

Valuing the potential benefits of different resource use strategies can help identify the optimal decisions (TEEB 2009). Within a region, sustainability can be achieved through exploration of constraints, trade-offs, and human values examined at multiple scales [9]. The major challenge is to understand the dynamics of interaction between ecosystem services and human well-being at both reginal and global levels under changing circumstances [10]. What mixes of ecosystem services do people prefer? How do human choices and actions affect local flows of ecosystem services and spill over to affect

\footnotetext{
${ }^{1}$ Natural capital. progect. http://www.naturalcapitalproject.org
} 
other regions? What institutions, incentives, and regulations are effective in sustaining flows of ecosystem services? [11].

The ecosystem services concept implies not only ecosystem conservation and recovery, but also providing the information necessary for efficient social and economic decision-making. Awareness of the necessity for new efficient approaches to managing human behavior towards the ecosystems is currently rising [12]. The concept of ecosystem services is crucial for identifying a new approach to solving social and economic problems [13]. The methodology of ecosystem services economic assessment has been widely investigated and the obtained results have indicated that different methods of economic valuation should be used including those accounting for intangible values [14]. It is crucial to use a combination of methods to valuate the ecosystem services for the further management decision making [15]. The research on nonmarket methods of valuating recreation services in Italy and northern Europe countries has proved the importance of these methods for decision- making $[16,17]$.

Valuating ecosystem services is necessary to ensure that ecosystem services contributing to human well-being and the policy aimed at socio-ecological systems sustainability are interconnected. The particular attention is paid to valuating tangible and intangible benefits, getting information from stakeholders' surveys [18, 19]. Edwards et al. (2012) and Giergiczny et al. (2016) also point at the importance of the complex approach to forest ecosystem services assessment $[20,21]$.

The Swedish scientists lay emphasis on the integrated landscape approach to forest management [22]. The subjective opinion should also be taken into account when using nonmarket methods of valuation [23]. The Federal agencies perform different actions having an environmental impact, without informing the society on the value of the particular ecosystem. The subjective wellbeing approach to preferencebased valuation is not used, however, this could reveal the ecosystem potential to supply people with the important regulatory services, as well as the social significance of the services supplied [24].

Quite recently, considerable attention has been paid to simulating ecosystem service flows and their accounting for decision making on landscape planning [25], agricultural land use planning [26], biodiversity conservation [27]. There are different projects aimed to solve particular management tasks $[28,29]$.

The model implementation implies great amount of continuously updating information, including that on public opinion on this or that issue. For this purpose, computer games can be used, which allow investigating ecosystem service synergies and collecting information from a wide audience relatively cheaply and quickly. This approach can make a revolution in ecosystem service research and assessment. Simulation games could contribute to understanding and managing ecosystems in the public interest [30].

In theory, nature is highly valued and environmental investments are believed to contribute to human well-being. In practice, scientific and political communities have not developed any scientific principles or regulations for financing the integration of natural capital into large-scale decisionmaking [31].

To develop the national sustainable development policy, all natural resources should be valued [32]. To obtain all necessary data, the integrated system of monitoring the natural capital value is to be developed. This system should be based on environmental-economic accounting, which provides a coherent set of indicators and descriptive statistics on the natural capital in compliance with the UN principles [33]. The integrated monitoring system will allow combining scientific knowledge on ecosystem services with the departmental information [34]. The integrated data obtained through monitoring the value of the natural capital are based on expert evaluation, national statistics, cadastral information, as well as the data of natural resources accounting and environmental monitoring [35]. The particularity of environmental-economic accounting is that all environmental assets are accounted for in terms of physical and monetary values, which provides reliable information for making environmental management decisions. The authorities should be responsible for funding for economic assessment of ecosystem services, while the scientists should be provided with all necessary information [36].

In the Russian Federation, the local authorities are responsible for designing and implementing sustainable development programs and strategies $[37,38]$.

In attempt to diversify regional economy, many regions try to develop the industries based on regional resources, including biological ones [39]. More often than not, the regional programs on natural resources management are focused on ecosystem production function, while regulatory, cultural, informative [40], and recreational functions remain beyond the scope of the authorities' attention and are not regarded within strategic planning. However, these resources ensure the quality of life and human well-being [41, 42]. Current national research on ecosystem service valuation is profound enough to implement the obtained knowledge in practice, however, this is impossible without federal departments participating in the process - currently, the national departments responsible for the natural capital valuation in compliance with international standards fail to perform these activities [43]. As she suggests, Russia needs a federal compensational environmental-economic mechanism for accounting regional ecosystem and eco-service values at both national and global scales.

In the TEEB report, it is stated that the global integration of ecosystem services into decision making will benefit from dissemination of best national practices. Forest ecosystem conservation is a major challenge if there is a regional need for the land industrial development and reclamation. For example, in Indonesia, over a period of 30 years, the monetary difference between deforestation and conservation was 2.5 billion US dollars. Most of this would have to be borne by local communities who would benefit from forest conservation (mainly through water supply, non-timber forest products, flood prevention, tourism and agricultural production). Valuation of forest resources within Ob-Tomsk interfluve 
conducted in the course of our research showed that the value of food is 30-fold higher than that of timber [44].

From the outcomes of our investigation, it is possible to conclude that to account all ecosystem services, the natural resource management department needs a new integrated monitoring system supported by the regional management system. Developing the monitoring system will involve formulating new requirements to information quality and funding for information provision. Therefore, the first step in the initiative implementation is to determine the possibility and estimate readiness of people in charge of decision making for ecosystem service assessment.

\section{MATERIALS AND METHODS}

To investigate the problem of ecosystem services in decision making, we have analyzed the outcomes of national and global scientific research. In the course of our investigation, we used the data of Russian state statistics, strategic plans and regulation of Tomsk Oblast, the departmental information, and the outcomes of previous research on the natural capital valuation in Tomsk Oblast [45]. Tomsk Oblast case study was conducted to determine the possibility and estimate readiness of the authorities to account economic benefits and losses in ecosystem management and perform ecosystem service accounting for management decision making.

\section{RESULTS AND DISCUSSION}

In our opinion, the criteria to estimate readiness to assess ecosystem services at the regional level are as follows:

- executive authority in charge of developing the natural resources management policy within the region;

- the environmental monitoring system being operated;

- the staff qualified and experienced in economic assessment of ecosystem services.

Tomsk Oblast in the subject of the Russian Federation and one of the regions in the Siberian Federal District. The total area is 314.4 thousand $\mathrm{km} 2$. Forests cover about $60 \%$ of the area. Tomsk Oblast is rich in natural resources, such as oil, gas, peat, ores, etc. 2 It also meets all the criteria mentioned above. The Strategy of Tomsk Oblast Development till 2020 considers the issue of sustainable development which is highlighted at all stages of planning.

The development of natural resources cluster in Tomsk Oblast is boosted due to the fact that the environmental economics is amongst the priorities of Tomsk Oblast social and economic development and is supported at all levels of government. Amongst the indicators of the Program implementation efficiency there is "natural capital of Tomsk Oblast", which reflects the increase in the renewable resources value due to advanced processing of the greater amount of raw materials in the course of the cluster development. The Program incentive arrangements are aimed at developing the

\footnotetext{
2 Investmentportal of Tomsk region Overview. http://www.investintomsk.com/tomskaya_oblast/obwie_svedeniya/\% $20 /$
}

technology of natural resources replenishment, advanced processing of resources, which is contributed by the universities and scientific centers, and creating products, goods, and services with enhanced consumer appeals to be supplied onto national and international markets. In the annual report of the governor, it is mentioned that the economy starts with accurate accounting of the natural resources, which allows efficient resource distribution, creating thousands of workplaces in villages and taiga settlements, improving business and investment performance 3 .

However, there is another program currently implemented in Tomsk Oblast, i.e. development of the forest complex, and the program priority is to increase timber production. The Strategy of Forest Complex Development in Tomsk Oblast till 2025 implies 2.5-fold increase in logging, 2.3-fold increase in timber production, and 3.3-fold increase in wood board production by 2025 . Rise in the amount of raw materials processed with the advanced technologies will allow improving wood resources efficiency within Tomsk Oblast, however, the issue of the forest complex development regarding non-wood resources has not been considered yet [46]. It is clear that corrupted data might be obtained if the economic assessment of natural resources is carried out neglecting ecosystem approach, which in its turn can cause planning errors.

The analysis of logging industry in Tomsk Oblast showed that there is an urgent need for economic-ecological valuation of the natural resources used in different ways . The integrated dynamics analysis of logging, forest regeneration, and fireinduced tree mortality dynamics demonstrated that the logging area extends while forest regeneration area tends to shrink.

Obviously, forest regeneration fails to compensate for fireinduced ecosystem losses. It is also noteworthy that logging and the use of non-wood resources including forest food are performed within the same areas. Logging in distant areas (40$100 \mathrm{~km}$ ) is non-remunerative because of the costs for transportation. Therefore, within short-distance areas the speed of deforestation exceeds the speed at which the forest can be regenerated. The national legislation system allows multiple forest land use. If to consider the forest land use types, the use of forest for food resources is predominant and accounts for $81 \%$ of the total area, while logging is performed within the area which makes up $6 \%$.

Besides logging, deforestation is also caused by natural resources exploration and production, construction of linear facilities (power lines, petroleum pipelines - 7\%), game husbandry $-5 \%$. The proportion shows that logging causes loss of forest productivity. As for non-wood resources, they are parts of the forest ecosystem, therefore, if the ecosystem disappears, all the resources are lost as well.

Also, Tomsk Oblast is currently implementing the state program "Development of the Renewable Resources Industry",

A. ${ }^{3}$ The report of the govenor at the Meeting of Legislative Duma of Tomsk Oblast within the action report of the executive authorities over the period of 2014 . Electronic resource:

http://gubernator.tomsk.ru/words/doklad-gubernatora-nasobranii (retrieved May 25,.2015) 
which implies the increase in wild crop yield from 10.5 thousand $\mathrm{m} 3$ in 2016 to 16 thousand $\mathrm{m} 3$ in 2020, as well as establishment of new workplaces. However, the discrepancies in land use cause unaccounted implementation risks.

As for forest crop, the yield has been rising except for 2014, when there was a decrease due to unfavorable weather conditions (table 1), and the amount of the yield is planned to increase.

TABLE I. FOREST CROP YIELD WITHIN TOMSK OBLAST (TONS)

\begin{tabular}{|l|l|l|l|l|l|l|}
\hline $\begin{array}{c}\text { Forest } \\
\text { crop }\end{array}$ & $\mathbf{2 0 0 9}$ & $\mathbf{2 0 1 0}$ & $\mathbf{2 0 1 1}$ & $\mathbf{2 0 1 2}$ & $\mathbf{2 0 1 3}$ & $\mathbf{2 0 1 4}$ \\
\hline Mushrooms & 907 & 915 & 1803 & 657 & 2070 & 1590 \\
\hline Berries & 924 & 1227 & 2927 & 3091 & 4019 & 2752 \\
\hline $\begin{array}{l}\text { Garden } \\
\text { berries }\end{array}$ & 842 & 519 & 1386 & 1670 & 1033 & 755 \\
\hline Nuts & 2316 & 922 & 3300 & 2864 & 1198 & 560 \\
\hline $\begin{array}{l}\text { Minor } \\
\text { orest } \\
\text { products }\end{array}$ & - & - & - & - & 748 & 1121 \\
\hline
\end{tabular}

There are also other types of forest land use. Within Tomsk Oblast, there are 28 animal species and 50 bird species, which are legally hunted. In 2014, some species declined mink, wood grouse, hazel hen.

The reason for decline might be shortage of food caused by either natural and weather conditions or human activities. As for hunting, it is also planned to increase both the number of animal species and hunting bag. Though there has been an increase in the use of all forest resources, there is still no assessment of the ecosystem production potential. For example, mushrooms, berries, and nuts used as food source by the majority of animals are planned to be picked in greater amounts. However, the decline in the number of animals indicates food shortage.

There is a controversy between using forest lands for different purposes and the increased forest resource exploitation since economic benefits for one land user will become losses for the other. The reduce the risks inherent to some forest land-use activities, the integrated renewable resource database is developed, which will contain the information on continuous monitoring of ecosystem service economic value. This will allow determining the priority landuse type, as well as the amount of compensation for forest land users whose interests are infringed.

Monitoring ecosystem service economic value is undoubtedly essential, for example, in terms of the information on land rent flows within forest food production sector. In particular, in the course of our research we used the monitoring data on prices and costs of picking forest crop and its pretreatment - drying and freezing [47] to assess the crop economic value in 2013 (table 2).

TABLE II. ECONOMIC VALUATION OF SOME FOREST FOOD RESOURCES, TOMSK OBLAST

\begin{tabular}{|l|c|c|c|c|}
\hline Forest crop & $\begin{array}{c}\text { Amount } \\
\text { of forest } \\
\text { crop } \\
\text { yield in } \\
\mathbf{2 0 1 3} \\
\text { tons }\end{array}$ & $\begin{array}{c}\text { Average } \\
\text { procure } \\
\text { ment } \\
\text { price, } \\
\mathbf{\$} / \mathbf{k g}\end{array}$ & $\begin{array}{c}\text { Net } \\
\text { value in } \\
\text { business, } \\
\mathbf{\$} / \mathbf{k g}\end{array}$ & $\begin{array}{c}\text { Total } \\
\text { economic } \\
\text { value in } \\
\mathbf{2 0 1 3} \\
\text { million } \mathbf{\$}\end{array}$ \\
\hline Mushrooms & 2070 & 2 & $5.7^{*}$ & 11.7 \\
\hline Berries & 4019 & 2.3 & 2.3 & 9.2 \\
\hline Nuts & 1198 & 6.7 & 1.2 & 1.5 \\
\hline Total & 8321 & & & 22.4 \\
\hline
\end{tabular}

It is worth noting that this is only a part of all forest crop yield since the information was obtained from the reports of big companies. Forest crop picked for household use and commercially by minor companies were not accounted. The data obtained showed that the greatest value added items are mushrooms. Moreover, the range of mushrooms and berries picked for household use is significantly wider. Also, in 2013, there was a failure of pine nut crop. As experts estimate, commercial forest crop yield accounts for $15 \%$, while the rest percentage of wild crop is picked for household use and fails to be statistically accounted. Therefore, it is important to ensure concordance between the particular resource-based industries to eliminate the factors that hinder their development.

Timiryazevo pine forest located in the immediate vicinity of Tomsk with population over 600 thousand serves as an example for implementing ecosystem service valuation into decision making. Besides performing recreation functions, the forest is the sources of food and medicinal herbs for both local communities and city dwellers.

We compared the value of Timiryazevo pine forest ecosystem resources with that of logging (value for clear-cut). The value of recreation services measured via WTP (willingness to pay for the area conservation) was 16.9 million dollars per year (table 3 ).

TABLE III. VALUATION OF SOME ECOSYSTEM SERVICES

\begin{tabular}{|l|l|}
\hline \multicolumn{1}{|c|}{ Ecosystem services } & $\mathbf{2 0 1 2}$ \\
\hline $\begin{array}{l}\text { Provisioning ecosystem services: net profit of wild } \\
\text { berries and mushrooms, million dollars per year }\end{array}$ & 2.7 \\
\hline $\begin{array}{l}\text { Culture services (recreation services, aesthetic } \\
\text { pleasure) in terms of willingness to pay, million } \\
\text { dollars per year }\end{array}$ & 16.9 \\
\hline $\begin{array}{l}\text { Regulatory services (absorbing carbon dioxide), } \\
\text { million dollars per year }\end{array}$ & 3.4 \\
\hline Total, million dollars per year & 23 \\
\hline Logging value (clear-cutting), million dollars per year & 16.3 \\
\hline
\end{tabular}

Compared with 2000, there has been a four-fold increase in WTP, while the total value of forest food resources has insignificantly decreased due to their shortage caused by human activities. These data initiated measures to reduce the anthropogenic load and support the ecosystem service flow. The total value of ecosystem services was 23 million dollars per year. In case of conservation, the ecosystem will provide the sustainable income for an unlimited period of time, with the income tending to increase under favorable conditions. The value of logging (as for clear-cut) would be 16 million dollars causing abandonment of all ecosystem services. In the result of the comparison analysis conducted by local authorities logging was banned within the area. 
The examples considered demonstrate that to develop and operate an efficient system of natural resource management, it is crucial to get complete and up-to-date information on ecosystem service flows in time and space. For this purpose, the state statistics should be improved. Another important issue is the data on ecosystem services particularly important for local communities. This requires regulations on municipal monitoring, which includes social surveys.

The analysis of natural resource management in Tomsk Oblast has shown that the local authorities are stepping up efforts to involve renewable resources into regional economy, thus providing new workplaces and increasing the budget income. Neglecting economic valuation of ecosystem services in the process of decision making can be hazardous for both ecosystem and local communities.

To ensure sustainable development of innovation-driven industrial cluster of renewable natural resources in the region, it is necessary to carry out economic valuation of renewable resource, assess the ecosystem capability for sustained and undiminished yield of renewable resources, develop a system of measures for environmental protection and conservation, and design the technologies of natural resources replenishment (including forest regeneration, recovery of fauna and flora, etc.).

The findings of the research indicate that people in Russia are aware of the necessity of implementing ecosystem service valuation into decision making at regional and national levels. However, economic valuation of ecosystem services is carried out occasionally and fails to go beyond the scope of scientific research. In practice, the research outcomes have not been widely disseminated. The research findings were put into practice in the works by G. Fomenko [48], in which they are used to develop the economic mechanisms of biodiversity conservation within recreation areas.

Currently, scientific and technical basis for implementing ecosystem service valuation into decision making at the national scale is reliable enough, however, the authorities are not ready for the changes in management system. We suppose that all ecosystem services accounting for management decision making can be implemented if the different approaches to natural resource management are integrated, which implies not only accounting, but assessing the impacts of policies and decisions on ecosystem services. There is an urgent need to implement a new integrated monitoring system based on economic valuation and supported by the regional management system, which requires institutional changes.

Institutional changes imply development of new statistical factors specifying information on environmental assets used by the companies in terms of physical and monetary values. For this purpose, the state statistics service should develop and approve new methods of statistical survey, while the federal natural resource management departments are to develop new indicators based on economic valuation of ecosystem services. It is necessary to legislate the ways in which the data are collected, approve the indicators, vest the departments in local authorities with powers to collect the information. Currently, there is a department responsible for natural resource management and in charge of environmental monitoring and informing stakeholders. However, environmental monitoring should also contribute to collecting information on the natural capital flows and ecosystem services supplied.

To provide all necessary data, it is crucial not only to improve statistical reports the natural capital valuation, but also create a legislative framework for municipal monitoring of the natural capital and ecosystem services, including the information on volumes and prices of the natural resources consumed. Such a system will allow information exchange and feedback in communication between the authorities and natural resource users, which in its turn ensures adaptive management in the face of uncertainty.

Continuous information exchange, data openness and availability will encourage natural resource users to efficient performance of their activities. This process will be boosted by establishing payments for ecosystem services and implementing environmental management system. The information on the natural capital used and ecosystem services supplied, open and available for local communities, will encourage people to use natural resources in the efficient way and to ensure environmental protection.

\section{CONCLUSIONS}

Today, economic valuation of ecosystem services is essential to improve natural resource management, which should be based on cost-benefit analysis of all ecosystem services provided.

Since natural resource management activities are carried out under the constantly changing conditions, there is a need for a flexible management system based on environmental impact monitoring, which implies economic assessment of ecosystem services distribution.

Though the local authorities are aware of the necessity for ecosystem approach to natural resource management, in practice there is no integrated development planning for different industries, which are closely connected with ecosystem sustainability.

Having considered the issue on whether the ecosystem approach can be integrated into natural resource management at regional level, namely, Tomsk Oblast, one can claim that there are no institutional conditions for implementation of ecosystem monitoring based on economic valuation and no mechanism for accounting ecosystem service economic values for decision making.

To coordinate current trends in natural resources management, there should be a new data set, i.e. a new integrated monitoring system based on economic valuation of the natural capital and supported by the regional management system. The system is supposed not only to provide specialists with all necessary information, but also to ensure interaction between the authorities, municipal organizations, and public.

\section{REFERENCES}

[1] G.C. Daily, P.A., Matson Ecosystem services: From theory to implementation. Proc Natl Acad Sci USA 105, 2008, pp. 9455-9456.

[2] B. Nyberg, Adaptive management: strategies for coping with change and uncertainty, in Dimensions of Sustainable Development, [Eds. Reinmar Seidler, and Kamaljit S. Bawa], in Encyclopedia of Life Support 
Systems (EOLSS), Developed under the Auspices of the UNESCO, Eolss Publishers, Oxford ,UK, [http://www.eolss.net] [Retrieved December 28, 2010].

[3] L. Boithias, M. Terrado, L. Corominas, G. Ziv, V. Kumar, M Marqués, M. Schuhmacher and V. Acuñ, "Analysis of the uncertainty in the monetary valuation of ecosystem services" - A case study at the river basin scale. Science of the Total Environment 543, 2016, pp. 683690.

[4] B. Fisher, K. Turner, P. Morling, "Defining and classifying ecosystem services for decision making", Ecological Economics 6 8, 200 9, pp. 6 $43-653$.

[5] R. S. Groot, M. A. Wilson, R. Boumans, "A typology for the classification, description and valuation of ecosystem functions, goods and services", Ecological Economics 41, 2002, pp. 393-408.

[6] R. Costanza, R. de Groot, P. Sutton, S. Ploeg, S. J. Anderson, I. Kubiszewski, S. Farber and R. K. Turner. "Changes in the global value of ecosystem services", Global Environmental Change 26, 2014, pp. $152-158$.

[7] WAVES, Wealth accounting and the valuation of ecosystem services, 2015 .

[8] The Economics of Ecosystems and Biodiversity (TEEB). The Economics of Ecosystems and Biodiversity: Mainstreaming the Economics of Nature: A Synthesis of the Approach, Conclusions and Recommendations of TEEB, 2010

[9] Cavender-Bares, P. Balvanera, E. King end S. Polasky, "Ecosystem service trade-offs across global contexts and scales Ecology and Society", 2015, 20(1): 22. http://dx.doi.org/10.5751/ES-07137-200122.

[10] J. Hauck, C Albert, C. Furst, D. Geneletti, D, La Rosa,

[11] S.R Carpenter, et al. "Science for managing ecosystem services: beyond the Millennium Ecosystem Assessment”, Proc. Natl. Acad. Sci. U.S.A., 106, 2009, pp. 1305-1312.

[12] L. Mononena, A.P. Auvinenc, A.L., Ahokumpud, M. Rönkäe, N. Aarrasf, H. Tolvaneng,M. Kamppinenh, E. Viirretd,g, T. Kumpulab, P. Vihervaarad. "National ecosystem service indicators: Measures of social-ecologicalsustainability”, Ecological Indicators 61, 2016, pp. 2737.

[13] A. Vazim, V Romanyuk, K Ahmadeev and I Matveenko "Associated petroleum gas utilization in Tomsk Oblast: energy efficiency and tax advantages," IOP Conference Series: Earth and Environmental Science, 2015, vol. 27, 5 p., http://dx.doi.org/10.1088/1755-1315/27/1/012078

[14] C. Quintas-Soriano, B. Martın-Lopez, F. Santos-Martın, M. Loureiro, C. Montes, J. Benayas and M. Garcia-Llorente. "Ecosystem services values in Spain: A meta-analysis", Environmental Science \& Policy 55, 2016, pp. 186-195.

[15] L. V. Rasmussen, O. Mertz, A. E. Christensen, F. Danielsen, N. Dawson and P. Xaydongvanh. "A combination of methods needed to assess the actual use of provisioning ecosystem services", Ecosystem Services 17, 2016, pp. 75-86.

[16] M. De Salvo, D. Signorello. "Non-market valuation of recreational services in Italy: A meta-analysis", Ecosystem Services16, 2015, pp. 4762.

[17] A. Filyushkina, N. Strangec, M. Löf, E.E. Ezebilo, and M. Boman, "Non-market forest ecosystem services and decision support in Nordic countries", Scandinavian journal of forest research, 2016, vol. 31, no. 1 , 99-110.

[18] M.E. Mastrangelo, F. Weyland, L. P. Herrera, S.H. Villarino, M.P. Barral, and A. D. Auer. "Ecosystem services research in contrasting socio-ecological contexts of Argentina: Critical assessment and future directions", Ecosystem Services16, 2015, pp. 63-73.

[19] S. Antognelli, M. Vizzari, "Ecosystem and urban services for landscape liveability: A model forquantification of stakeholders' perceived importance", Land Use Policy, 50, 2016, pp. 277-292.

[20] D. M. Edwards, M. Jay, F. S. Jensen, B. Lucas, M. Marzano, C. Montagné, A. Peace, and G. Weiss, "Public preferences across Europe for different forest stand types as sites for recreation", Ecology and Society, 2012, 17(1): 27. http://dx.doi.org/10.5751/ES-04520-170127.
[21] M. Giergiczny, M. Czajkowski, T. Żylicz, and P. Angelstam, "Choice experiment assessment of public preferences for forest structural attributes", Ecological Economics, 2015, pp. 119, 8-23

[22] P. Angelstam, K. Andersson, R. Axelsson, M. Elbakidze, B.G. Jonsson, \& Roberge, J.-M. Protecting forest areas for biodiversity in Sweden 1991-2010: the policy implementation process and outcomes on the ground. Silva Fennica, 2011, 45(5), pp. 1111-1133.

[23] N. Stoeckl, M. Farr, S. Larson, V. M. Adams, I. Kubiszewski, M Esparon and R. Costanza. "A new approach to the problem of overlapping values: A case study in Australia's Great Barrier Reef". Ecosystem Services10, 2014, pp. 61-78.

[24] L. Olander, R. Johnston, H. Tallis, J., Kagan L. Maquire, J. Boyd, S. Polasky and L. Wainger Best Practices for Integrating Ecosystem Services into Federal Decision Making, 2015, [Online]: http://hdl.handle.net/1903/16751.

[25] De Montis, A., Caschili, S., Mulas, M., Modica, G., Ganciu, A., Bardi, A., Ledda, A., Dessena, L., Laudari, L. and Fichera, CR. "Urban-rural ecological networks for landscape planning". Land Use Policy, 50, 2016, pp. 312-327.

[26] F. Lerouge, K. Sannen, H. Gulinck and L. Vranken. "Revisiting production and ecosystem services on the farm scale for evaluating land use alternatives", Environmental Science \& Policy 57, 2016, pp. 50-59.

[27] J.E. Cordingley, A.C. Newton, R.J. Rose, R.T. Clarke, J.M. Bullock "Can landscape-scale approaches to conservation management resolve biodiversity-ecosystemservice trade-offs", Journal of applied ecology Vol. 53, 2016, pp. 96-105.

[28] S.M. Posner, E. McKenzie and T. H. Ricketts. Policy impacts of ecosystem services knowledge [Online] http://www.pnas.org/content/early/2016/01/25/1502452113.

[29] P. W. Jorgensen, D. C. Trotter and T. R. Hill, "Ecosystem services assessments in local municipal decision making in South Africa: justification for the use of a business-based approach", Journal of environmental planning and management Vol. 59(2), 2016, pp. 263-279

[30] R. Costanza, K. Chichakly, V. Dale, S. Farber, D. Finnigan, K. Grigg, S. Heckbert, I. Kubiszewski, H. Lee, S. Liu, P. Magnuszewski, S. Maynard, N. McDonald, R. Mills, S. Ogilvy, P. L. Pert, J. Renz, L. Wainger, M. Young and C.R. Ziegler. "Simulation games that integrate research, entertainment, and learning around ecosystem services", Ecosystem Services10, 2014, pp. 195-201.

[31] H. Tallis, A. Guerry, G. C. Daily. "Ecosystem Services", Ecological Systems. 2012, pp 81-100.

[32] Millennium Ecosystem Assessment, Ecosystems \& human well-being: synthesis report, Island Press, 2005.

[33] Integrated Environmental and Economic Accounting. Final draft circulated for information prior to official editing. Handbook of National Accounting. Studies in Methods. - New York: United Nations,Series F, 61, Rev.1, 2003.

[34] R. Chaplin-Kramer, M. Jonell, A. Guerry, E. F. Lambin, A.J. Morgan, D. Pennington, N. Smith, J, A. Franch, and Polasky S. "Ecosystem service information to benefit sustainability standards for commodity supply chains", Annals of the new york academy of sciences. 1355, 2015, pp. 77-97 New York Academy of Sciences.

[35] M. R., Tsibulnikova, F. R., Satayev, O. A. Ilchenko "Peculiarities and problems of geoinformational sources development for natural resources management problem solution", Bulletin of the Tomsk State University, vol. 346, 2011, pp. 193-197.

[36] I., R. Kubiszewski, N. E. Costanza, M. A. Gorko, A. W. Weisdor, C Carnes, E. Collins, C. Franco, L. R. Gehres, J.M. Knobloch, G. E. Matson and J. D. Schoepfer. "Estimates of the Genuine Progress Indicator (GPI) for Oregon from 1960-2010 and recommendations for a comprehensive shareholder's report", Ecological Economics 119, 2015 , pp. $1-7$

[37] G.N Romashkina. "On the development of cost-accounting of natural resources in Russia", Questions of Statistics, vol.9, 2010, pp. $32-43$.

[38] G.A. Fomenko, M.A. Fomenko, E.A. Popova, O.V. Ladygina, "Problems and prospects of development of publicly available statistica basis of accounting and evaluation of environmental resources", Problems of regional ecology. vol.1, 2013, pp. 75-86 
[39] V.E. Rokhchin, V.S. Uskov, "Ways to enhance the economic turnover of fruit and berry production in the region ", Economic and Social Changes: Facts, Trends, Forecast. vol.4, 2014, pp. 198-211.

[40] E. Mociora, M. Kruse. "Educational values and services of ecosystems and landscapes - An overview ", Ecological Indicators 60, 2016, pp. 137-151

[41] P. Bolund, S. Hunhammar, "Ecosystem services in urban areas", Ecological Economics 29, 1999, pp. 293-301.

[42] S. Engel, S. Pagiola, S. Wunder, "Designing payments for environmental services in theory and practice: An overview of the issues", Ecological Economics 6 5, 2008 , pp. $663-674$.

[43] G.D. Titova, "Ecosystem services valuation: a potential application in practice ", Bulletin of the Trans-Baikal State University. vol.3 (118), 2015, pp. 179-191

[44] M. Tsibulnikova, I. Sharf, "Valuing Ecosystem Services in Wildlife Management ". Proceedings of the 26th International Business Information Management Association Conference, Madrid, Spain, November 11-12, 2015, pp. 1054-1059.

[45] M.R. Tsibulnikova, "Peculiarities of Rent Flows Formation in the Area of renewable natural resources and the Necessity of their Accounting for Regional Development ", Journal of Agricultural Science and Technology A. vol.1, 2011, pp. 532-535.

[46] M.R. Tsibulnikova, O.V. Pogharnitskaya "Problems of sustainable forest management in the socio-economic regions development siberian federal district ". Modern problems of science and education. vol.6, 2013, pp. 469.

[47] S. Litvinov, Business "Wild plants": a manual for entrepreneurs / SS. Litvinov. - Tomsk: Publishing house "Print Manufactory", 2014, 102 p.

[48] Innovation management algorithm for the conservation of protected areas in terms of reducing budget financing / Ed. GA. Fomenko and others Yaroslavl: NPP "Cadastre", 2003, 88 p. 
